\title{
POLA PIKIR PEREMPUAN DALAM NOVEL-NOVEL KARYA NH DINI (KAJIAN ANALISIS ISI)
}

\author{
Nini Ibrahim dan Prima Gusti Yanti \\ Universitas Muhammadiyah Prof. Dr. Hamka \\ niniibrahim13@yahoo.com
}

\begin{abstract}
Abstrak: Penelitian ini bertujuan untuk mengkaji sebuah karya sastra dengan menggunakan analisis isi, sekaligus mengetahui representasi pola pikir berupa disipliner, mensintesa, kreasi, penghargaan, dan etis serta peranan wanita dalam novel-novel karya Nh. Dini.Dalam penelitian ini, penulis menggunakan metode penelitian kualitatif deskriptif dengan teknik analisis isi. Metode penelitian deskriptif adalah salah satu jenis penelitian yang berusaha menggambarkan dan menginterpretasi objek sesuai dengan apa adanya. Kegiatan penelitian ini dilakukan dengan cara mencari, mengumpulkan, membaca, dan mempelajari artikel-artikel atau laporan-laporan yang berhubungan dengan objek penelitian. Hasil yang diperoleh bahwa pola pikir perempuan yang paling mendominasi digambarkan oleh Nh. Dini dalam novelnovelnya ialah pola pikir mensintesa (The Synthesizing Mind) yaitu kemampuan menyampaikan hasil integrasi dari pemikirannya pada orang banyak. Pola pikir sintesa melatih kesadaran untuk berpikir luas dan fleksibel dan mau menerima sudut pandang dari multi disiplin.
\end{abstract}

\section{Kata kunci: Pola pikir, perempuan, novel}

\section{PENDAHULUAN}

Salah satu masalah yang sering muncul dalam karya sastra adalah subordinasi perempuan. Perempuan dikondisikan dalam posisi yang lebih rendah dari laki-laki. Kondisi ini membuat perempuan berada dalam posisi tertindas, inferior, tidak memiliki kebebasan atas diri dan hidupnya. Dalam hal ini, perempuan dikondisikan sebagai makhluk yang lemah sedangkan laki-laki dikondisikan sebagai makhluk yang kuat. Akibatnya peran perempuan sering diabaikan dalam kehidupan publik karena perempuan hanya cocok dalam peran keluarga saja.

Nh. Dini adalah novelis wanita Indonesia yang paling subur produktivitasnya. Karyakarya Nh. Dini menyuarakan tentang perjuangan perempuan yang juga rajin membicarakan permasalahan dominasi laki-laki dan konstruksi sosial yang sangat patriarkal melalui novelnya. Selain itu, pembaca dihadapkan pada permasalahan-permasalahan kehidupan perempuan yang terjadi saat ini.

Dengan gaya ketenangan seorang wanita, Nh.Dini mampu menghadirkan perjuangan, pergulatan, dan pemberontakan wanita dalam mencari jati diri dan kebebasan. Walau sekecil apapun kebebasan yang didapat, tokoh Sri dalam novel pada Sebuah Kapal, atau tokoh Hiroko dalam roman yang sama, tampak dengan gigih memperjuangkannya. 
Berdasarkan periode sastra karya Nh.Dini di antaranya: (1) Pada Sebuah Kapal (1972), (2) Pertemuan Dua Hati (1986), (3) Hati yang Damai (1998), (4) Jepun Negerinya Hiroko (2000), dan (5) Argenteul: Hidup Memisahkan Diri (2008).

Menjadi seorang penulis bukanlah hal yang mudah seperti membayangkan karakter dari setiap tokoh. Selain itu, membangun pola pikir dari tokoh yang akan dimunculkan, turut menjadi seni tersendiri bagi si penulis. Seperti Nh Dini yang memberikan gambaran pola pikir perempuan dalam tokoh-tokoh di novel-novelnya. Terkait hal tersebut, Novel-novel karya Nh. Dini dapat dijadikan sebuah penelitian mengenai pola pikir perempuan. Untuk mengetahui sikap serta pandangan seorang perempuan yang memiliki perbedaan dalam masalahnya.

Adapun masalah yang dirumuskan dalam penelitian ini yaitu bagaimana pola pikir perempuan dalam novel-novel karya Nh. Dini dengan teknik analisis isi. Pola pikir yang akan dikaji meliputi dari pola pikir 1) disipliner, 2) mensintesa, 3) kreasi, 4) penghargaan, dan 5) etis.

\section{METODE}

Dalam penulisan penelitian, penulis menggunakan metode penelitian kualitatif deskriptif dan analisis isi. Metode penelitian kualitatif deskriptif adalah salah satu jenis penelitian yang berusaha menggambarkan dan menginterpretasi objek sesuai dengan apa adanya (West, 1982:19). Dengan penelitian metode kualitatif deskriptif, memungkinkan peneliti untuk melakukan hubungan antar variabel, menguji hipotesis, mengembangkan teori yang memiliki vadilitas universal (west, 1982).

\section{HASIL DAN PEMBAHASAN}

\section{Hasil}

Berdasarkan hasil analisis pola pikir perempuan dalam novel-novel karya Nh. Dini, sebagai berikut.

\begin{tabular}{llccccc}
\hline \multirow{2}{*}{ No } & \multirow{2}{*}{ Novel } & \multicolumn{5}{c}{ Pola Pikir } \\
\cline { 3 - 7 } $\mathbf{1}$ & Pada Sebuah Kapal & 4 & 8 & 3 & 3 & 4 \\
$\mathbf{2}$ & Pertemuan Dua Hati & 12 & 16 & 7 & 12 & 32 \\
$\mathbf{3}$ & Hati Yang Damai & 2 & 17 & 4 & 3 & 2 \\
$\mathbf{4}$ & Jepun Negerinya Hiroko & 5 & 4 & 4 & 5 & 2 \\
$\mathbf{5}$ & Argenteuil: Hidup & 5 & 6 & 5 & 4 & 2 \\
& Memisahkan Diri & & & & & Kreasi \\
\hline
\end{tabular}




\section{Pembahasan}

\section{Pola pikir disipliner}

\section{- Pada Sebuah Kapal}

Dalam novel ini pola pikir disipliner yang muncul tidak lebih dari 4 temuan. Seperti sikap Sri yang menunjukkan bahwa pola pikir yang didapatkan, dipelajari berdasarkan pembelajaran atau pendidikan formal sebelumnya. Seperti pada kutipan:

"Bagiku, ini (membaca buku-buku cerita bahasa Inggris) merupakan satu-satunya jalan untuk lebih mengenal bahasa yang semakin penting bagi orang-orang yang mengingnkan kemajuan di segala lapagan."

- Pertemuan Dua Hati

Dalam novel ini pola pikir disipliner yang muncul melebihi dari novel Pada Sebuah Kapal yaitu \pm 12 temuan. Seperti sikap Bu Suci kalau pada saat-saat tertentu timbul pemberontakan yang berupa kemarahan dan kemudian mengarah keamukan tentulah disebabkan karena dia kurang atau tidak diberi ajaran mengendalikan diri.

\section{- Hati Yang Damai}

Sama halnya dengan Pada Sebuah Kapal, novel Hati Yang Damai pola pikir disipliner yang muncul tidak lebih dari 2 temuan. Seperti sikap ibu Dati, Nh. Dini memberikan gambaran perempuan zaman dahulu bahwa seorang perempuan tidak perlu pergi bersekolah. Lihat pada kutipan berikut. “...Ibuku tidak mengaharapkan aku menjadi perempuan sekolahan. Dan aku tinggal dengan kemuraman yang semakin mengerikan."

\section{- Jepun Negerinya Hiroko}

Dalam novel Jepun Negerinya Hiroko ini yang tergambarkan sebagai pola pikir disipliner terdapat 5 kutipan dalam temuan. Hal ini tergambar dalam kutipan yang menggambarkan pola pikir disipliner "Aku lebih suka mendengarkan percakapan lingkungan intelek yang sangat menarik itu”. Kutipan tersebut menggambarkan Dalam hal ini Dini terlihat sebagai perempuan yang berinteltual tinggi, sehingga dalam kehidupannya ia lebih suka berkumpul dengan orang yang memiliki inteltual juga. Inteletual Dini membentuk pola piker Dini yang sangat cerdas.

\section{- Argenteuil: Hidup Memisahkan Diri}


Dalam novel Argenteuil: Hidup Memisahkan Diri, serupa dengan Pertemuan Dua Hati bahwa \pm 5 temuan dari pola pikir disipliner. Salah satu pola pikir disipliner pada kutipan berikut: “...Lintang memulai ajaran di kelas terminal. Dia akan menempuh ujian guna mendapatkan Ijazah baccalaureat di ujung tahun. Aku tidak terlalu risau mengenai kemampuannya di bidang studi.” Ini menunjukkan bahwa pemikiran Dini yang selalu percaya akan kemampuannya anaknya itu. sedangkan lintang mengikuti ujian itu secara pendidikan formal

\section{Pola pikir mensintesa}

\section{- Pada Sebuah Kapal}

Dalam novel ini, pola pikir mensintesa ditemukan paling banyak dibandingkan dengan pola pikir lainnya yaitu berjumlah \pm 8 temuan. Hal ini dapat dilihat bahwa Nh. Dini memberikan gambaran kepada pola pikir perempuan untuk memikirkan dan mencermati segala sesuatu sebelum bertindak. Namun bukan berarti seluruhnya tindakannya berjalan baik.

\section{- Pertemuan Dua Hati}

Pada novel Pertemuan Dua Hati, pola pikir mensintesa juga ditemukan hampir banyak dibandingkan dengan pola pikir lainnya, sekitar \pm 16 temuan. Salah satu penggambaran Nh. Dini dalam pola pikir mensintesa yaitu “...Kekuatan jiwa seseorang seringkali tergantung dari cukup tidaknya dia menerima kasih sayang di masa kecil. Kemudian, pengasuhan keluarga, pendidikan agama dan sekolah menjadi perlengkapan seterusnya."

\section{- Hati Yang Damai}

Pada novel ini, pola pikir mensintesa juga paling banyak ditemukan dibandingkan pola pikir lainnya, sekitar \pm 17 temuan. Salah satu kutipan yang mengandung pola pikir mensintesa karya Nh. Dini, yaitu pada kutipan; “...Aku adalah istri terkutuk yang mengingkari kesetiaan dan kecintaan suamiku. Aku yang setiap kali melihat dan mendendam mendengar perbuatan orang lain dengan cibiran bibirku, kini telah menodai diri dengan perbuatan yang jauh lebih hina."

\section{- Jepun Negerinya Hiroko}

Pada novel ini, pola pikir mensintesa ditemukan berjumlah 4 buah dalam hasil analisis novel Jepun Negerinya Hiroko. Pola pikir mensintesa pada novel ini menggambarkan tokoh Dini sebagai perempuan yang juga berpendidikan, Dini banyak memiliki pengetahuan yang tinggi. Ia ingin memiliki kebebasan seperti yang ia inginkan. Sikap 
Yves yang berubah setelah menikah membuat Dini merasa tidak nyaman karena terkekang oleh suaminya tersebut. Penggambaran tersebut didukung dengan kutipan “Tetapi aku tidak menyukai cara suamiku mengekang diriku. Perilaku itu demikian berbeda dari yang kukenal: Yves sebagai lelaki yang dermawan, selalu memanjakan aku termasuk saudara-saudaraku, bahkan rekan-rekanku di Kemyoran”.

\section{- Argenteuil: Hidup Memisahkan Diri}

Pada novel ini, pola pikir mensintesa tidak terlalu mendominasi seperti novel-novel lainnya. Penggambaran hasil analisis pola pikir ini dalam dilihat pada kutipan berikut. “...Pengemasan barang lancar dan sesuai dengan kehendakku. Kusengaja bersikap mantap dank eras ketika berhadapan dengan para petugas pindahan, karena aku tahu, bahwa kebanyakan dari mereka memandang rendah kaum perempuan. Apalagi yang berkulit coklat seperti diriku."

\section{Pola pikir kreasi}

\section{- Pada Sebuah Kapal}

Dalam novel ini, pola pikir kreasi ditemukan tidak lebih dari 3 temuan, sama halnya dengan analisis pola pikir disipliner. Dapat dilihat penggambaran Nh. Dini tentang pemikiran perempuan terkait dengan kreasi yaitu “...Aku sehat, aku bekerja dan ingin terus menari. Tapi tidak hendak sampai di sini saja. Aku telah diajar Sutopo untuk memiliki sesuatu, untuk maju di suatu lapangan. Sebagai penyiaraku tidak bisa maju lagi. Tapi sebagai penari."

\section{- Pertemuan Dua Hati}

Dalam novel ini, pola pikir kreasi tidak lebih dari 7 temuan. Hal ini tidak jauh berbeda dengan novel Pada Sebuah Kapal. Salah satu contoh kutipan yang dikategorikan sebagai pola pikir kreasi adalah "...Pengertian orang biasanya lebih dapat diharapkan jika dia diajak berunding."

\section{- Hati Yang Damai}

Dalam novel Hati Yang Damai, pola pikir kreasi hanya 4 temuan. Dapat dilihat bahwa Nh. Dini menggambarkan pemikiran perempuan pada zamannya sulit untuk membangun kreasi-kreasi dari masyarakat yang ada.

\section{- Jepun Negerinya Hiroko}

Dalam novel Jepun Negerinya Hiroko pola pikir kreasi terdapat hasil analasis sebanyak 4 buah kutipan yang menggambarkan pola pikir kreasi. Kutipan yang menggmabrkan pola pikir kreasi ini adalah "Aku lebih suka diberitahu jauh-jauh hari 
jika suamiku mengundang orang makan dirumah kami. Dengan demikian aku bisa memasak dengan lebih tenang".

\section{- Argenteuil: Hidup Memisahkan Diri}

Pada novel ini, pola pikir kreasi tidak lebih dari 5 temuan yang digambarkan oleh Nh. Dini. Salah satu kutipan pola pikir kreasi yang tergambar adalah “...Tapi seketika itu juga pikiranku membubung ke angkasa, mengucapkan syukur kepada Yang Maha Kuasa. Inilah kesempatan yang diberikan kepadaku. Inilah jawaban atas doa-doaku. Aku harus bisa mempengaruhi Lintang, dia yang tidak begitu bersemangat jika menyebut-nyebut Perguruan Tinggi di Amerika."

\section{Pola pikir penghargaan}

\section{- Pada Sebuah Kapal}

Pada novel ini, pola pikir penghargaan hanya terdapat 3 temuan. Nh. Dini memberikan gambaran pola pikir perempuan dalam novelnya, lebih menitikberatkan pada masalah batin tokohnya. Sedikit sekali menemukan pola pikir penghargaan terhadap orang lain maupun diri sendiri.

\section{- Pertemuan Dua Hati}

Dalam novel Pertemuan Dua Hati, Nh. Dini memberikan pola pikir perempuan lebih banyak dibandingkan novelnya yang lain. Lebih dari 12 kutipan yang mengandung pola pikir penghargaan, seperti pada kutipan “...Tidak ada orang baik atau pandai atau cekapan dalam segala-galanya. Kamu termpil dalam hal pertukangan, otakmu cerdas meskipun pelajaranmu biasa-biasa saja."

\section{- Hati Yang Damai}

Pada novel Hati Yang Damai dalam memberikan gambaran mengenai pola pikir penghargaan, tidak banyak ditemukan pada tokoh perempuan. Dati lebih banyak memberikan sintesanya dibandingkan sebuah penghargaan, mengingat bahwa sejak kecil ia haus akan kasih sayang. Dati hanya bisa memberikan bentuk penghargaan pada dirinya sendiri. Lihat pada kutipan berikut. “...Aku sudah puas dengan hidupku yang sekarang; seperti kau, aku tidak memikirkan hidupku nanti."

\section{- Jepun Negerinya Hiroko}

Pada novel Jepun Negerinya Hiroko ini memberikan gembaran pola pikir penghargaan. Hasil analisis dalam novel ini terdapat 5 buah kutipan. Berikut ini kutipan yang menggambarkan pola pikir penghargaan "Dan semenjak aku mengenal 
kepelitannya dalam hal benda-benda yang kukenakan ataupun belanjaan sehari-hari, aku lebih suka tidak menyinggung soal uang dihadapan orang lain".

\section{- Argenteuil: Hidup Memisahkan Diri}

Pada novel ini, Nh. Dini memberikan pola pikir terkait penghargaan pada tokoh perempuan tidak lebih dari 5 kutipan. Salah sati kutipan yang menggambarkan penghargaan sebagai berikut “...Tentu aku amat terharu dan bersyukur menerima warisan tanda kedermawanan majikanku tersebut. Selama hampir setengah tahun itu kehidupanku berjalan cepat penuh peristiwa dan perubahan, seolah-olah digesekan oleh waktu.

\section{Pola pikir etis}

\section{- Pada Sebuah Kapal}

Pada novel ini, pemikiran dari perempuan mengenai pola pikir etis tidak tergambar secara dominan, hanya 3 kutipan yang terdapat di dalam novel, yang mengandung pola pikir etis. Lihat pada kutipan berikut. “...Kami tinggal di kampung, tetapi ibuku tidak mau kalau anak anaknya dipengaruhi oleh sikap dan ajaran orang-orang biasa. Baginya seorang anak perempuan adalah wakil dari kehalusan, kesucian, dan keindahan.. “

\section{- Pertemuan Dua Hati}

Pada novel ini, pola pikir perempuan mengenai etis ditunjukkan pengarang melalui dialog si "Aku”, seperti pada kutipan. "Sebagai wanita berkarir, aku tetap merasa lebih tenang jika dapat bekerja sekailus mengawasi anak-anak. Mengajar di satu tempat dengan sekolah anakku merupakan impian yang ideal.” Pola pikir etis merupakan sikap yang bertanggung jawab moral yang tinggi dari beberapa aspek. Dalam novel ini, pola pikir etis sangat terlihat \pm 12 kutipan untuk dianalisis.

\section{- Hati Yang Damai}

Dalam novel ini, pola pikir etis tidak tampak hanya sedikit dari pemikiran perempuan yang dihadirkan oleh Nh. Dini. Seperti pada kutipan berikut. "Tentu saja aku merasakannya. Aku bahkan terkejut menerima perbedaan dunia luar itu. Tapi Wija menolongku. Wija menghadapkan aku ke dunia pergaulan yang sebenarnya antara manusia dan sahabat sesama kerja." Pola pikir yang terdapat dalam pikiran Dati, bahwa Wija mampu bertanggung jawab dan membedakan sesuatu hal dari beberapa aspek. 


\section{- Jepun Negerinya Hiroko}

Pada novel ini, sikap atau pola pikir mengenai etis berdasarkan hasil analisis sangat sedikit ditemukan berjumlah 2 buah kutipan yang menggambarkan sikap atau pola pikir mengenai etis. Hal ini didukung oleh kutipan berikut "Aku adalah seorang patriot tulen yang tidak menganggap agama atau idealisme berada di atas segala-galanya”.

\section{- Argenteuil: Hidup Memisahkan Diri}

Pada novel ini, sikap atau pola pikir mengenai etis lebih tampak. Terdapat lebih dari 4 kutipan yang mengandung pola pikir etis, salah satu kutipan tersebut ialah “...Kami sebagai orangtua memberi pengarahan kepada anak, bahwa budaya kita berlainan dan sudah bagus begini untuk dilanjutkan. Jangan karena ini menjadi modern, lalu meniruniru kebiasaan orang di belahan dunia lain." dimana orang tua dapat memiliki tanggung jawab kepada anaknya untuk memberikan arahan yang baik.

\section{SIMPULAN}

Pola pikir perempuan dalam novel-novel Nh. Dini meliputi dari disipliner, mensintesa, kreatif, penghargaan, dan etis. Pada pelukisan pola pikir, Nh. Dini menuangkan pemikiran perempuan dengan sederhana di setiap novelnya. Pola pikir yang digambarkan dalam novel, tidak mendominasi seluruh aspeknya, seperti dalam novel Pada Sebuah Kapal pola pikir yang mendominasi adalah mensintesa, novel Pertemuan Dua Hati pola pikir yang mendominasi adalah etis, novel Hati Yang Damai pola pikir yang mendominasi adalah mensintesa, novel Jepun Negerinya Hiroko pola pikir yang mendominasi adalah disipliner dan penghargaan, dan novel Argenteuil: Hidup Memisahkan Diri pola pikir yang mendominasi adalah disipliner. Akan tetapi, secara umum novel-novel yang dianalisis telah tergambar pola pikir seorang perempuan dalam novel-novel Nh. Dini.

\section{REFERENSI}

Agni, Binar. 2008. Sastra Indonesia Lengkap. Jakarta: Hi-Fest Publishing

Dweck, Carol S., 2008. Change Your Mindset. Diakses dari:

http://rachmatsoegiharto.blogspot.co.id/2013/04/apa-sih-pola-pikir-itu.html. Diunduh pada hari kami, tanggal 1 Desember 2016. Pukul. 08.00 WIB

Endaswara, Suwardi. 2011. Metodologi Penelitian Sastra. Yogyakarta: Pustaka Pelajar.

Fakih, Mansour. 2012. Analisis Gender dan Transformasi Sosial. Yogyakarta: Pustaka Pelajar.

Gardner, Howard. 2005. Five Minds of Future. Diakses dari:

http://www.nuriazhari82.web.id/2016/01/pola-pikir-manusia-kreatif-menurut-para.html.

Diunduh pada hari kami, tanggal 3 Desember 2016. Pukul. 10.00 WIB 
Kutha Ratna, Nyoman. 2013. Teori, Metode, dan Tehnik Penelitian Sastra. Yogyakarta: Pustaka Pelajar.

Nurgiyantoro, Burhan. 2010. Teori Pengkajian Fiksi. Yogyakarta: Gadjah Mada University Press.

Stanton, Robert. 2012. Teori Fiksi Robert Stanton. Yogyakarta: Pustaka Pelajar.

Sugihastuti. 2010. Gender dan Inferioritas Perempuan. Yogyakarta: Pustaka Pelajar.

Tarigan, Henry Guntur.1984. Prinsi-prinsip Dasar Sastra. Bandung: Angkasa.

Wahyuningsih, Fahmi. Perjuangan Tokoh Emansipasi Perempuan Indonesia dan Jerman.

Fakultas Bahasa dan Seni, Universitas Negeri Surabaya. (Lentera, Jurnal Studi

Perempuan Vol. 9. No. 1, Juni 2013)

http://duniakorap.wordpress.com/2011/02/26/nilai-\%E2\%80\%93-nilai-dalam-karyasastra/Phianzi1989.blogspot. Diunduh pada hari kami, tanggal 4 Desember 2016. Pukul. 08.00 WIB

http://www.kamusq.com/2012/11/gender-pengertian-dan-definisi.html. Diunduh pada hari kami, tanggal 4 Desember 2016. Pukul. 10.00 WIB 